\title{
Europe on a Plate: Food, Identity and Cultural Diversity in Contemporary Europe
}

\author{
LARA ANDERSON \\ The University of Melbourne \\ laraba@unimelb.edu.au \\ HEATHER MERLE BENBOW \\ The University of Melbourne
}

\section{GREGORIA MANZIN}

\section{La Trobe University}

\begin{abstract}
This article discusses tensions emerging from conflicting ethnic and national identities in three European Union (EU) member states - Germany, Italy and Spain - through the prism of culinary practices. Food is a marker of cultural identity. In Europe, a wide variety of food practices and culinary cultures co-exist in close proximity, and Europeans thus face the dilemma that confronts all omnivores presented with a breadth of culinary options: while variety can bring the potential for enjoyment, the choice of something new can be perceived as a threat. Within this context, buffeted by the forces of globalisation, migration and supra-national EU regulation, culinary patterns associated with migration strive to come to terms with growing 'gastronationalism'. This article dissects the differences and similarities in the way this tension manifests in Germany, Italy and Spain. ${ }^{1}$
\end{abstract}

Key words: food; culture; Catalonia; Germany; Italy; Spain

\section{Introduction}

Food is a language we use to convey to others and to ourselves who we are. More than mere nourishment, food is an expression of identity. ${ }^{2}$ Therefore, food and food practices are an important form of discrimination between cultural groups and are often co-opted as 'signifiers of group culture and identity, wherein the items ingested say something meaningful about people, to themselves and others, in often openended processes of social identification that are at the heart of ethnic, national, class, gender, sexual, local and other identities'. ${ }^{3}$ In Europe, where culinary cultures jostle in

\footnotetext{
${ }^{1}$ Most of the work done by Gregoria Manzin on this article was conducted while she worked at The University of Melbourne.

${ }^{2}$ Anne Murcott, 'Food as an Expression of National Identity' in Sverker Gustavsson and Leif Lewin (eds.), The Future of the Nation State: Essays on Cultural Pluralism and Political Integration, Stockholm: NereniusSanérus, 1996, pp. 49-77.

3 Thomas. M. Wilson, 'Food, Drink and Identity in Europe: Consumption and the Construction of Local, National and Cosmopolitan Culture' in T. M. Wilson (ed.), Food, Drink and Identity in Europe, Amsterdam: Rodopi, 2006, p. 12.
} 
close proximity and are buffeted by the forces of globalisation, migration and supranational European Union (EU) regulation, food is at the heart of cultural identities. Europeans in the EU benefit from the culinary offerings of a staggeringly diverse array of European cultures, and increasingly also enjoy rich pickings from non-EU cuisines, thanks to post-war migration. However, concerns about the mixing of culturesEuropean and non-European - in the EU have also at times been expressed in worries about food. The pleasures and the pressures of globalisation, with the migration of peoples and products across borders, are felt especially keenly in a supra-national context like the EU. A particularly intense microcosm of globalising forces, it exhibits the benefits - and, lately, the tensions and conflicts - that arise from a shared economic destiny, as well as astonishing cultural diversity. This article explores identity as it is both asserted and consumed through the culinary discourses of culture in contemporary Europe. Tensions within the EU are perhaps now at an all-time high since the end of the Cold War, so it is opportune to ask: are the optimism and promise of the EU dissipating like so many champagne bubbles, or can the culinary communities of the EU still break bread together?

Food is inextricably linked to both individual and collective identity. Unlike other physical expressions of cultural specificity, such as clothing or bodily rituals, food is literally transformed and becomes part of the substance of the body. Thus, the saying 'you are what you eat' has 'several layers of meaning from the symbolic to the material'. 4 As Roland Barthes suggested, food, far from being merely a carrier of nutrients, calories and minerals, is also a semiotic system; its attendant rules and narratives, and the choices available, make of food and eating a means of communication (Barthes 1976). 5 While ethnology has long been concerned with documenting food practices as a key marker of cultural specificity, it was the anthropologists of the 1960 s and 1970 s who established the notion of cuisine as a language of sorts. And while language is often cited as the basis of a common identity, ${ }^{6}$ gastronomy, as Claude Levi-Strauss argued, is the only other 'truly universal form of human activity'.7

More recently, the link between culinary cultures and identity has been taken seriously in cultural, literary and food studies. Studies of national cuisine have demonstrated the positive relationship between culinary preferences and identities ${ }^{8}$ or the significance

\footnotetext{
4 Marianne Lien, 'The Politics of Food: An Introduction' in Marianne Lien and Brigitte Nerlich (eds.), The Politics of Food, Oxford, New York: Berg, 2004, p. 6

5 Roland Barthes, ‘Toward a Psychosociology of Contemporary Food Consumption' (1976) in Carole Counihan and Penny Van Esterik, Food and Culture: A Reader, $3^{\text {rd }}$ ed., New York, London: Routledge, 2013, pp. 28-35. See also Mary Douglas's demonstration that food is an expression of social identity and relationships in Mary Douglas, Food in the Social Order: Studies of Food and Festivities in Three American Communities, New York: Routledge, 1973 .

6 Benedict Anderson, Imagined Communities: Reflections on the Origin and Spread of Nationalism, $2^{\text {nd }}$ ed., London, New York: Verso, 1991, pp. 68-82.

7 Claude Levi-Strauss, 'The Culinary Triangle' in Marianne Lien and Brigitte Nerlich (eds.), The Politics of Food, Oxford, New York: Berg, 2004, p. 40.

${ }^{8}$ Ken Albala, Food in Early Modern Europe, Westport: Greenwood Press, 2003; Lara Anderson, Cooking up the Nation: Late-Nineteenth and Early-Twentieth-Century Spanish Culinary Texts and Culinary Nationalization, Woodbridge: Tamesis Books, 2013; Carol Helstosky, Garlic and Oil: Politics and Food in Italy, Oxford: Berg, 2004; Stephen Mennell, 'Culinary Transitions in Europe: An Overview’ in Darra Goldstein and Kathrin Merkle (eds.), Culinary Cultures of Europe: Identity, Diversity and Dialogue, Strasbourg: Council of Europe, 2005, pp. 469-488; Priscilla Parkhurst Ferguson, 'Culinary Nationalism', Gastronomica, Vol. 10, No. 1, 2010: pp. 102-109; Jeffrey Pilcher, iQué vivan los tamales!: Food and the Making of Mexican Identity, New Mexico: University of New Mexico Press, 1998.
} 
of food in national literatures. 9 Priscilla Parkhurst Ferguson sees cuisine as central to the construction of a French national identity, for instance; something confirmed in other studies of national cuisines. ${ }^{10}$ While these studies have added to our understanding of national food cultures in Europe, the integrated nature of the EU calls for research with a European focus, something that has only been partly addressed by edited books. ${ }^{11}$ In 2006, an edited collection of essays considered the context of European integration and the 'forces that will enhance or hinder the realization of an even closer European union,' 12 regarding eating and drinking in Europe as 'acts of identification, differentiation and integration'. ${ }^{13}$ Furthermore, acknowledging the important social and cultural role of food, the Council of Europe convened a working group in 2002 to explore the promotion of tolerance and diversity through food. ${ }^{14}$ The increasingly integrated - and multicultural - nature of the EU demands an intercultural focus in food research that accounts for the culinary impacts - positive and negative - of migration both from within and outside of Europe within a context of increasing 'gastronationalism'.

This article discusses the tensions emerging from conflicting ethnic and national identities in multicultural Europe. It does so by examining three case studies that outline the importance of food and food practices as markers of cultural identity. The case studies presented here stem from Germany, Spain and Italy, three nations in which the phenomenon of gastronationalism and its effects and consequences are easily observable, though they take different forms and shapes in each case. Gastronationalism is here intended as 'a form of claims-making and project of collective identity' that emphasizes the cultural capital attached to local food and food practices. 15 When food is incorporated into a specific cultural patrimony, it can also be read as a symbol of that patrimony's vulnerability to 'invasion' from a foreign culture, thus instigating quests of authenticity that link food to place. Statistically, Italy, Spain and Germany score very highly in the number of food products safeguarded by labels of national origin, ${ }^{16}$ an objective measure that can be used to identify the tendency towards gastronationalism. Furthermore, data from the Eurostat 2015 confirm that all three nations score equally highly relative to the percentage of non-EU migrants residing within their national borders. ${ }^{17}$ These two figures combined make the three selected countries apt starting points to investigate the theme of food and identity in contemporary Europe.

\footnotetext{
9 Alois Wierlacher, Vom Essen in der deutschen Literatur: Mahlzeiten in Erzähltexten von Goethe bis Grass, Stuttgart: Kohlhammer, 1987.

${ }^{10}$ Anderson, 2013; Arjun Appadurai, 'How to Make a National Cuisine: Cookbooks in Contemporary India', Contemporary Studies in Society and History, Vol. 30, No. 1, 1988, pp. 3-24; Annette Cozzi, The Discourses of Food in Nineteenth-Century British Fiction, New York: Palgrave Macmillan, 2010; Helstosky, 2004; Barbara Santich, 'With Fork and Pen in Nineteenth-Century Paris', Bibliofile, Vol. 11, No. 4, 2006: pp. 9-17.

${ }^{11}$ Darra Goldstein and Kathrin Merkle (eds.) Culinary Cultures of Europe: Identity, Diversity and Dialogue, Council of Europe Publication, 2005; Peter Schollier, Food, Drink and Identity: Cooking, Eating and Drinking in Europe since the Middle Ages, Oxford: Berg, 2001; HansTeuteberg, Gerhard Neumann and Alois Wierlacher (eds.), Essen und kulturelle Identität: Europäische Perspektiven, Berlin: Akademie Verlag, 1997; Thomas Wilson (ed.), Food, Drink and Identity in Europe, Amsterdam: Rodopi, 2006.

12 Wilson, 2011, p. 11.

13 ibid., p. 26.

14 Goldstein and Merkle (eds.), 2005.

15 Michaela DeSoucey, 'Gastronationalism: Food Traditions and Authenticity Politics in the European Union', American Sociological Review Vol. 75, No. 3, 2010: p. 433.

16 ibid., p. 440.

${ }^{17}$ Europe in Figures: Eurostat Yearbook, 2015, accessed 24 August 2015, http://ec.europa.eu/eurostat/statisticsexplained/index.php/Eurostat_yearbook
} 


\section{Contemporary Europe and the Omnivore's Dilemma}

We propose to consider the culinary diversity of Europe as a form of the 'omnivore's dilemma'. Europeans - more acutely than many peoples - are faced with the dilemma that confronts all omnivores presented with a breadth of culinary options: while variety brings with it the potential for enjoyment, the choice of something new also involves a risk, since food can be 'pleasant or poisonous'. 18 The 'omnivore's dilemma', first defined in detail by Paul Rozin (though Rousseau had already noticed it), describes what is at stake when we are presented with novelty in our diet. ${ }^{19}$ In biological terms, omnivores have the significant advantage of flexibility in their diets, but there is the real risk of poisoning or imbalance. The omnivore's dilemma can also be said to have a cultural dimension, one that is especially apparent in the EU context. On the one hand, introduced foods and dishes are devoured happily by Europeans, even in preference to local cuisines; the cuisines of migrant populations have been heartily embraced by local cultures across Europe. One need think only of Britain's chicken tikka masala and Germany's döner kebab as national dishes invented by migrants. ${ }^{20}$ There is also considerable cultural capital to be gained in the consumption of ethnic cuisines, as a recent study of English dining habits has shown. ${ }^{21}$ Likewise, the editor of the British Good Food Guide has described the decade of the 1990s as characterised by the waning of French culinary hegemony and the rise of multicultural 'fusion' in British haute cuisine. ${ }^{22}$ On the other hand, as Zygmunt Bauman argues, consumption is a source of anxiety precisely because it is constitutive of identity: the 'wrong' choices might convey unintended messages about the self. 23 Moreover, it seems that the residual biological anxiety before a novel cuisine that confronts us as omnivores may be fortified by existing prejudices about cultural difference. Our food choices involve ingesting otherness quite literally, so the encroachment of other culinary cultures can as easily be perceived as a threat to culinary identity. Indeed, the difficulty in accepting a new ethnic community or migrant group has been theorised in the Australian context as a kind of cultural 'indigestion,' expressed in concerns about contaminants in 'ethnic' food. ${ }^{24}$ And while a certain cosmopolitan sophistication can be conveyed by the enjoyment of a variety of non-native cuisines, equally, 'culinary xenophobia' 25 can find expression in fearful attitudes toward 'foreign' foods - for example, the Italian city of Lucca banned the opening of new ethnic and fast-food restaurants within its city walls in a bid to preserve its traditional culinary identity. ${ }^{26}$

\footnotetext{
${ }^{18}$ Paul Rozin 'Human Food Intake and Choice: Biological, Psychological, and Cultural Perspectives' in Harvey Anderson, John Blundell and Matty Chova (eds.), Food Selection: From Genes to Culture, Paris: Danone Institute, 2002, pp. 17.

19 ibid., pp. 7-24. See also Michael Pollan, The Omnivore's Dilemma: A Natural History of Four Meals, London: Penguin, 2006.

${ }^{20}$ Njeri Githire, 'The Empire Bites Back: Food Politics and the Making of a Nation in Andrea Levy's Works', Callaloo, Vol. 33, No. 3, 2010: pp. 857-873; Simon Richter, 'Food and Drink: Hegelian Encounters with the Culinary Other' in A. Phipps (ed.), Contemporary German Cultural Studies, London: Arnold, 2002, pp. 179-195.

${ }^{21}$ Alan Warde, Wendy Olsen and Lydia Martens, 'Consumption and the Problem of Variety: Cultural

Omnivorousness, Social Distinction and Dining Out', Sociology, February 1999, Vol. 33, No. 1: pp. $105-127$.

${ }_{22}^{2}$ Elizabeth Carter, 'The 6o Year Revolution', Delicious Magazine, 2011, accessed 20 February 2013.

http://www.deliciousmagazine.co.uk/articles/the-60-year-revolution

23 See Warde et al., 1999, p. 141.

${ }^{24}$ Louise Edwards, Stefano Occhipinti and Simon Ryan, 'Food and Immigration: The Indigestion Trope Contests the Sophistication Narrative', Journal of Intercultural Studies, Vol. 21, No. 3, 2000: pp. 297-308; Lara Anderson and Heather Merle Benbow, 'Cultural Indigestion in Multicultural Australia: Fear of 'Foreign' Foods in Australian Media', Gastronomica: The Journal of Food and Culture, Vol. 15, No. 1, 2015: pp. 34-43.

25 Barbara Santich, Looking for Flavour, Kent Town: Wakefield Press, 1996, p. 232.

${ }^{26}$ K. Cook, 'A Walled City in Tuscany Clings to Its Ancient Menu, New York Times, 13 March 2009, p. 13.
} 
The supra-national context of the EU also poses challenges. British tabloid newspapers can always rely on the EU's regulation of foodstuffs for a headline on a slow news day. The conflict between free trade and 'cultural patrimony' led to the creation of the EU's 'designation of origin' program in 1992 - a program not without its problems. Some argue it merely 'pickles' culinary heritage, precluding the organic development that is intrinsic to any continuous food tradition. ${ }^{27}$ These kinds of regulatory mechanisms exercised upon EU member countries have often been perceived as a threat to culinary identity. ${ }^{28}$ Ambivalence in the United Kingdom toward EU and European Economic Community (EEC) membership has long been expressed in worries about food. The British press habitually reports on the intrusion of European directives in the national life: between 1995 and 2004, 30\% of such newspaper stories were about food and drink. ${ }^{29}$ For example, in 2001, believing that 'Europe' was about to ban the sale of milk in glass bottles, the Sunday Telegraph remonstrated that 'another sliver of the British way of life bites the dust'.30

In Italy, too, there is increasing resentment of the EU's role in food regulation, which is viewed as a challenge to the Italian way of life and even to Italianness itself. As the birthplace of the Slow Food movement, Italy, perhaps more than any other nation, exhibits a strong awareness of the cultural politics of food, as well as a vigorous defence of culinary identity. According to Erick Castellanos and Sara Bergstresser, Euroscepticism is increasingly replacing the past enthusiasm for Europe in Italy. ${ }^{31}$ But despite the anxieties and negative imagery that proliferate in the popular media especially, it is important to bear in mind that the majority of Europeans still associate food and eating with pleasure, rather than with food-related risks. ${ }^{2}$ It is therefore critical to bear in mind both aspects of the omnivore's dilemma - the 'pleasure' and the 'poison' - when considering culinary diversity in Europe. 33 Only then can we begin to understand how culinary tensions can exist in Europe alongside the acknowledged pleasures of culinary diversity.

\section{Germany's Love-Hate Relationship with Turkish Germans and their Food}

Germany is exemplary of the culinary benefits and discomforts afforded by migration in Europe. Turkish work migration to Germany began in the early 1960s, but the culinary presence in Germany of between three and four million people of Turkish background (many of them now citizens) can still be conjured by one dish: the döner $k e b a b$. Similar to curry in Britain, this is a culinary import adapted to local tastes (Githire 2010). Derived from a Turkish dish, the döner is said to have originated in

\footnotetext{
${ }_{27}$ Julian Baggini, 'The Changing Taste of Food and Drink Traditions', The Guardian, 9 January 2014, accessed 29 January 2016, http://www.theguardian.com/lifeandstyle/2014/jan/o8/changing-taste-food-drink-tradition ${ }^{28}$ Eva Barlösius, 'Bedroht das europäische Lebensmittelreicht die Vielfalt der Eßkulturen?' in Hans Teuteberg, Gerhard Neumann and Alois Wierlacher (eds.), Essen und kulturelle Identität, Berlin: Akademie Verlag, 1997, pp. $113-130$.

29 Menno Spiering, 'Food, Phagophobia and English National Identity', in Thomas Wilson (ed.), Food, Drink and Identity in Europe, New York: Rodopi Press, 2006, pp. 31-48.

30 ibid., p. 43.

${ }^{31}$ Erick Castellanos and Sara Bergstresser, 'Food Fights at the EU Table: The Gastronomic Assertion of Italian Distinctiveness' in Thomas Wilson (ed.), Food, Drink and Identity in Europe, Amsterdam: Rodopi, 2006, pp. 179202.

${ }^{32}$ Eurobarometer, 'Special Eurobarometer 354: Food-related risks', Brussels: European Commission, 2010, accessed 24 August 2015, http://ec.europa.eu/public_opinion/archives/ebs/ebs_354_sum_en.pdf 33 Paul Rozin, 'Food is Fundamental, Fun, Frightening, and Far-Reaching', Social Research, Vol. 66, No. 1, Spring 1999: p. 17.
} 
Berlin in the 1970s, when a Turkish restaurateur saw a need for a transportable snack for German commuters. Today, the döner is touted as Germany's national dish (Richter 2002, p. 182). It is the dominant street food in a nation of Wurst-eaters, and a significant industry in economic terms: in 2010 the European döner industry centred upon Germany - was said to be worth 3.5 billion euros per year and to involve 200,000 jobs (Angelos 2012). But the ubiquity of the döner as a Turkish dish is not to be taken as evidence of a wholesale acceptance of Turkish Germans. As Githire points out in the case of Britain, such dishes, even when invoked as evidence of cultural acceptance, serve equally well as metaphors for cultural indigestion and intolerance. 34 The döner is sometimes invoked disparagingly in discussions of migration in Germany, perhaps because the rise of the döner coincided with the search for a German national cuisine in the 1980s, amid the nascent discourses of multiculturalism. 35

As a recent controversy showed, the culinary practices of Germany's largest minority still have the capacity to offend the mainstream. An area in central Berlin colloquially dubbed the 'Türkenwiese' (Turkish meadow), part of the Tiergarten park, was for many years a popular site for barbeques in summer, particularly among Turkish and Arab migrants. Families would bring large amounts of picnic equipment and their own barbeques and settle in for long days in the park. A ban on barbequing in the Tiergarten was implemented at the start of 2012, ostensibly due to the amount of refuse caused by the barbeques. But the ban - a cooperative undertaking of local politicians from the mainstream left and right - was dubbed the 'new philistinism' by a politician from the far left party. ${ }^{6}$ Online comments accompanying the announcement of the ban in the Berliner Zeitung welcome the move and complain about the smells and the mess associated with the migrants' barbequing. One suggests that the money saved on rubbish removal be redeployed for language education, a reference to one of the bugbears of 'integration' debates in Germany. 37 The same newspaper reports that since the ban was implemented, peace and tranquillity have returned to the park. An article describes a very German couple, she reading a book, he tapping quietly on his laptop:

Herbert Lütje and Elke Tiet are enjoying the unusual peace. The couple have made themselves comfortable on folding chairs. [...] It's the weekend but they are almost alone in the Tiergarten. Since the barbeque ban, the lawns are clean and the air is clear of smoke. Just a few cyclists and walkers can be seen. ${ }^{38}$

Under the title 'The Caravan Moves On', the article observes that parks in other areas of the city are now 'besieged' by people of migrant background. An Arab man is interviewed as he turns meat on the grill; it's reported that he greets another man, who is setting up 'camp' nearby, in Arabic. A gallery of photos depicts meat on the grill and migrant family groups amid the smoke. The article reports that in another area of Berlin, where barbeques have also recently been banned, a man pulled a knife on an

\footnotetext{
34 Githire, 2010.

35 Manuela Bojadžijev, 'Fremde Töpfe. Kulinarische Vorstellungen von Multikulturalismus' in Mark Terkessidis and Ruth Maer (eds.), Globalkolorit. Multikulturalismus und Populärkultur, St Andrä, Wörden: Hannibal, 1998, pp. 305 .

${ }^{36}$ Uwe Aulich, Birgitt Eltzel and Ulrich Paul, ‘Müllchaos Grillverbot im Tiergarten', Berliner Zeitung, 14 October 2011, accessed 20 June 2014, http://www.berliner-zeitung.de/berlin/muellchaos-grillverbot-imtiergarten,10809148,11010976.html

37 ibid.

$3^{8}$ Sebastian Höhn, ‘Grillen in Berlin Grillverbot Tiergarten: Karawane zieht weiter,' Berliner Zeitung, 12 June 2012, accessed 29 Jan 2016, http://www.berliner-zeitung.de/berlin/grillen-in-berlin-grillverbot-tiergarten-karawane-zieht-weiter,10809148,16351276.html
} 
enforcement officer. 39 The report's focus on Arab and Turkish families makes it clear that the man is most likely of Muslim migrant background.

It seems context is everything when it comes to the culinary practices of migrants in Europe. Dishes such as curry or the döner find broad acceptance as food for the general public, but similar food prepared by and for migrants themselves still has the capacity to arouse intercultural acrimony. Both the döner and the barbeque involve the grilling of meat in the (more-or-less) open. Yet, as the barbeque bans in Berlin attest, the innocuous döner finds a more threatening counterpart in the public barbeques of Turkish migrant families.

Integrated threat theory, first proposed by social psychologists Stephan, Stephan and Gudykunst, explains the difficulties and prejudices - both real and symbolic 40 - that arise from intergroup relations. ${ }^{41}$ Intergroup threat is most likely between groups with a long history of conflict. ${ }^{2}$ It is striking that the language used in the coverage of the barbeque ban in Berlin evokes the era of Ottoman greatness, when Turks laid siege to Vienna. One Turkish-German journalist cheekily describes the Tiergarten pre-ban as looking like the camps outside Vienna during the Ottoman-era sieges of that city, and asks, 'How did they ever manage to get rid of the Turks at Vienna?'. 43 The Berliner Zeitung also reaches for the language of military conflict to describe the authorities' confrontation with the grillers: 'For the municipal office of Mitte the Tiergarten is a pacified zone'. 44 The barbeque conjures images of a latter-day Ottoman 'invasion', replete with the malevolent, knife-wielding barbarian who threatens the peace of Berlin's calm green spaces. As this example shows, the food of migrants in Europe has an enduring capacity to both delight and offend.

\section{The Fortification of Regional Cuisine: The Case of Italy}

The concept of 'Fortress Europe' entered public discourse in the 1980s, with immigration becoming one of the EU's major concerns in the 1990s. 45 A special report commissioned by the EU in 2000 on racism and xenophobia confirmed that from 1997 to 2000 the presence of minorities was increasingly associated with a perceived threat to social peace and welfare. 46 The increase of migration to the EU has had an impact on Italy in particular, as it is one of the member states most targeted as an entry point into Europe. 47 Ambrosini reports a $12.7 \%$ average yearly growth in the number of

\footnotetext{
39 ibid.

40 Walter G. Stephan and C. Lausanne Renfro, 'The Role of Threats in Intergroup Relations' in Diane Mackie and Eliot. R. Smith (eds.), From Prejudice to Intergroup Emotions, New York: Psychology Press, 2002, pp. 191-208. ${ }^{41}$ Walter G. Stephan, Cookie White Stephan and William B. Gudykunst, 'Anxiety in Intergroup Relations: A Comparison of Anxiety/Uncertainty Management Theory and Integrated Threat Theory', International Journal of Intercultural Relations, 1999, Vol. 23: pp. 613-628.

$4^{2}$ Michal Shamir and Tamy Sagiv-Schifter, 'Conflict and Political Tolerance in Israel' in Gerson Moreno-Riaño (ed.), Tolerance in the Twenty-first Century: Prospects and Challenges, Oxford: Lexington Books, 2006, pp. 97112.

43 Hatice Akyün, Einmal Hans mit scharfer Soße: Leben in zwei Welten, Munich: Goldman, 2005, p. 34.

44 Höhn, 2012.

45 Hans-Joerg. Albrecht, 'Fortress Europe? Controlling Illegal Immigration', European Journal of Crime, Criminal Law and Criminal Justice, Vol. 10, No. 1, 2002: pp. 1-22.

${ }^{46}$ Eva Thalhammer, Vlasta Zucha, Edith Enzenhofer, Brigitte Salfinger, Günther Ogris, 'Attitudes Towards Minority Groups in the European Union', A Special Analysis of the Eurobarometer 2000, Survey on Behalf of the European Centre on Racism and Xenophobia, Vienna 2001, viewed 28 January 2016,

http://mnie.geo.uni.lodz.pl/raporty/rasizm2001.pdf, pp. 7, 15 .

47 Europol, 'Joint Operational Team Launched to Combat Irregular Migration in the Mediterranean', accessed 17

March 2015, https://www.europol.europa.eu/content/joint-operational-team-launched-combat-irregularmigration-mediterranean
} 
immigrants living within Italian borders between 2006 and 2013.48 In line with the 2000 Special Eurobarometer report, Diamanti's 2011 study reveals that over 50\% of Italian citizens view immigrants as a threat to security.49 In the 2008 national election, the issue of illegal migration was a major item in the electoral campaign, one that certainly contributed to the striking victory scored by the centre-right coalition. ${ }^{\circ}$

A 2009 report commissioned by the Institute of Local Finance and Economy (IFEL) also revealed that among the main causes of concern for residents of major urban centres were safety and micro-criminality, which $24 \%$ of the surveyed population attributed to the increase in migration..${ }^{1}$ As reported by Ambrosini, following the 2008 election, several municipalities primarily located in the northern regions and predominantly administered by centre-right local councils issued a series of by-laws, among which figured 'reinforcing ordinances' aimed at strengthening previous proscriptions. $5^{2}$ Amid these measures, policies of economic exclusion occupied a prominent position. In the name of safety and urban decorum, and also invoking the need to protect local culinary traditions and specialties, local authorities imposed a range of restrictions to 'ethnic' business activities operating in the food industry. These restrictions ranged from an overt control of businesses' opening times to the prohibition of consuming any food in public in focal urban areas. More worryingly, in several municipalities, the 2008 security package vetoed the opening of new ethnic eateries or mandated their relocation. 53 As reported by the national newspaper $L a$ Repubblica, this is what happened in the Tuscan town of Lucca. 54 Its centre-right coalition banned the opening of outlets that served food linked to 'different ethnicities' within the city walls (four square kilometres), even when those businesses had bought out pre-existing eateries. The newspaper identified kebab sellers as the first 'victims' of the new local ordinance. For a more recent case, we need go no further than Tuscany where, in 2011, the centre-left mayor of the renowned beach town of Forte dei Marmi passed a similar decree preventing the opening of any new ethnic restaurant. 55 This was interpreted as a further sign of the culinary nationalism that has swept the peninsula in recent years, but the mayor Umberto Buratti denied any connection to xenophobic trends and emphasized instead the need to 'protect' and 'value' the Italian national culinary tradition. ${ }^{6}$ Far from being isolated incidents, these episodes were compounded by a new ordinance in the city of Verona in March 2014 that sparked debate. The city council, despite having recently lost a court case for a similar 2011

\footnotetext{
${ }^{48}$ Maurizio Ambrosini, “'We Are Against a Multi-Ethnic Society”: Policies of Exclusion at the Urban Level in Italy', Ethnic and Racial Studies, Vol. 36, No. 1, January 2013: p. 139.

49 Ilvo Diamanti, La sicurezza in Italia e in Europa. Significati, immagine e realtà. Quarta indagine sulla rappresentazione sociale e mediatica della sicurezza, Rome: Fondazione Unipolis, 2011, p. 10.

50 Anna Triandafyllidou and Maurizio Ambrosini, 'Irregular Immigration Control in Italy and Greece: Strong Fencing and Weak Gate-Keeping Serving the Labour Market', European Journal of Migration and Law, Vol. 13, 2011: p. 263.

${ }^{51}$ CITTALIA, Oltre le ordinanze: I sindaci e la sicurezza urbana, Rome: Associazione nazionale Comuni Italiani, 2009 , p. 77.

$5^{2}$ Ambrosini, 2013, p. 142.

53 ibid., p. 148.

${ }^{54}$ La Repubblica, 26 January 2009, 'Lucca, Stop ai ristoranti etnici, 'Salvaguardare la tradizione', accessed 10 August 2015, http://www.repubblica.it/2009/o1/sezioni/cronaca/lucca-etnico/lucca-etnico/lucca-etnico.html 55 Corriere della Sera, 'Forte dei Marmi, il sindaco mette al bando kebab e involtini primavera', 9 October 2011, viewed 17 March 2015, http://www.corriere.it/cronache/11_ottobre_o9/forte-dei-marmi-ristoranti_106eee3ef261-11eo-9a3e-cd32c1odad62.shtml?refresh_ce-cp

${ }^{6}$ The Telegraph, 14 October 2011, 'Italian Town Bans Any New Kebab Shops or Other 'Ethnic Food', accessed 24 August 2015, http://www.telegraph.co.uk/foodanddrink/foodanddrinknews/8827721 /Italian-town-bans-anynew-kebab-shops-or-other-ethnic-food.html
} 
ordinance due to its 'discriminatory nature', enforced a new ban on the production and sale of ethnic food. 57

Besides overt bans, other types of controls obstruct the business operation of non-local food sellers. In 2014, the province of Udine in the region of Friuli-Venezia Giulia, whose administration is led by the right-wing Lega Nord (Northern League), tightened the controls for food-safety standards in take-away venues and 'ethnic' eateries. ${ }^{8}$ This initiative followed a very similar action launched in Venice a few months earlier. 59 The regional president of Friuli-Venezia Giulia, Pietro Fontanini, declared that these controls were aimed at ensuring that kebab shops and other 'ethnic' eateries adhere to the same standards and regulations as businesses selling products 'made in Italy' and 'made in Friuli'.60

If the town of Verona was motivated by the necessity of protecting typical products bound to the local culinary heritage, in Lucca - to return to the 2009 case cited above - the town council went as far as specifying that eateries located within the city walls had to include at least one local specialty prepared with local produce in their menus. ${ }^{61}$ Cases like these draw attention to the fine line separating protectionist policies from xenophobic restrictions. As DeSoucey points out, 'claims for the protection of particular foodstuffs as nationally significant help us understand the revitalization of practices or items considered traditional during times when old identities are perceived to be in jeopardy'. ${ }^{62}$ The same study confirms that Spain, Germany, and Italy all currently figure among the six EU countries with the highest rates of label registrations under the three available schemes: Protected Designation of Origin (PDO), Protected Geographical Indication (PGI), and Traditional Specialty Guaranteed (TSG).

Amid numerous legal battles to protect specific products and specialties, such as parmigiano reggiano and pizza napoletana, Italy has become famous for its Slow Food movement. ${ }^{6}$ An organization established in the 1980 s by Carlo Petrini, it initially focused on the protection of regional traditions and the defence of a 'slow paced' life. 64 With time, Slow Food grew to win international recognition and consequently expanded its agenda. Fifteen years after its establishment, Slow Food 'began to imagine itself as an international organization concerned with the global protection of food tastes'. 65 Promoting local producers and businesses and campaigning to deter the process of globalization in agriculture are two of the organization's principal tasks. There is, however, a downside to this form of safeguarding of local customs and produce. As Marie Sarita Gaytán highlights, Slow Food equally engages in the creation of 'a collective identity by preserving past traditions, while shunning contemporary consumption habits that [its members] feel threaten particular cultures and culinary

\footnotetext{
57 Corriere di Verona, 'Riesplode la guerra del kebab. Cibi etnici: stop a nuovi locali', 5 March 2014, accessed 24 August 2015, http://www.sivempveneto.it/vedi-tutte/20348-verona-riesplode-la-guerra-del-kebab-cibi-etnicistop-a-nuovi-locali-norma-voluta-dallassessore-corsi-pd-e-grillini-assurdo

${ }^{8}$ Il Piccolo, 25 March 2014, 'Fontanini dichiara guerra a kebab e falafel', accessed 27 August 2015,

http://ilpiccolo.gelocal.it/trieste/cronaca/2014/o3/25/news/fontanini-dichiara-guerra-a-kebab-e-falafel1.8915611

59 ibid.

60 ibid.

${ }^{61}$ La Repubblica, 26 January 2009.

62 DeSoucey, 2010, p. 442.

63 ibid.

64 Slow Food International, http://www.slowfood.com, accessed 24 August 2015.

65 Alison Leitch, 'Slow Food and the Politics of Pork Fat: Italian Food and European Identity', Ethnos: Journal of Anthropology, Vol. 68, No. 4, 2003: p. 446.
} 
practices'. ${ }^{66}$ By seeking to actively shelter traditional or endangered food products, Slow Food implicitly reinforces the process of marginalization of migrant culinary cultures spread across the Italian territory, insofar as these are perceived as a potential threat for autochthonous food realities. Thus, while an international entity like Slow Food can empower local producers to launch campaigns seeking to protect specific local and/or endangered products (see, for instance, the case of Colonnata lard), 67 the now recognized cultural value of selected local food products acts as a driver for the marginalization of potentially competing foreign cuisines and their products.

Yet, despite the restrictive legislative measures implemented in these recent years, public interest in ethnic food is alive and growing, as testified to by the perceived need to control the number of ethnic eateries scattered throughout the Italian peninsula. If gastronationalism remains a strong and visible tendency, still multi-ethnic cuisine is endorsed and further promoted in major public forums. Interestingly, during the opening in Milan of Expo 2015 (whose theme was 'Feeding the Planet'), the mistrust and aversion that resulted in a plethora of restrictions towards the production and consumption of ethnic food was replaced by the rhetoric of cultural and culinary diversity in celebration of multi-ethnic cuisine. In its first month, Expo Milan dedicated an entire week to gastronomic delights originating in, among others, Chinese, Tunisian, Egyptian and Congolese cuisines, thus essentially promoting the culinary practices of migrant groups elsewhere potentially categorized as threatening. In this way, despite numerous attempts to limit the diffusion of and restrict access to multi-ethnic food through targeted legislative manoeuvres, multi-ethnic food is a reality in Italy that the general public does not categorically shun. While Slow Food has an important role for the preservation and renewal of century-long local food traditions, Italy's composite, multi-ethnic society also finds its expression through a changing culinary scenario in which local products can co-exist alongside new, migrant-based specialties.

\section{Spanish Culinary Xenophobia and Catalonian 'Home-Building' Food Multiculturalism}

Spain has been just as subject to gastronationalism as Germany and Italy. There have also been instances of striking culinary xenophobia in the Spanish media, especially towards the Chinese and their cuisine. The Spanish television channel Telecinco, for instance, has been the subject of a number of controversies in recent years. In December 2014, an offensive skit was included in the channel's Christmas Eve gala special, 'La noche en paz'. Titled 'Mesa para dos' (Table for two), and produced by José Luis Moreno, the sketch mocked the quality and service of Chinese restaurants in Spain, and suggested that they serve dog meat. ${ }^{68}$ Huang Yazhong, charge d'affaires of the Chinese Embassy in Spain, wrote to Telecinco, demanding an apology. He expressed his strong dissatisfaction over the sketch, which he viewed as an overt insult to the Chinese. China was again unimpressed when a second incident aired on the same channel, this time involving Aída Nízar, a former contestant on Spain's version of Big Brother. In May 2014, Nízar filed a report for the talk show Sálvese quien pueda in which she accused Chinese restaurants in Spain of poor hygiene, including using dirty

\footnotetext{
${ }^{66}$ Marie Sarita Gaytán, 'Globalizing Resistance: Slow Food and New Local Imageries’, Food, Culture and Society, Vol. 7, No. 2, 2004: p. 102.

${ }^{67}$ Leitch, 2003.

${ }^{68}$ El Mundo, 9 January 2014, 'Pekín muestra su pesar por comentarios contra chinos en Telecinco', accessed 16 July 2015, http://www.elmundo.es/television/2014/o1/o9/52cecce1226o 1d38228b456c.html
} 
water, and of cooking with human and cat meat. ${ }^{69}$ This caused significant damage to the local Chinese catering industry and led to uproar from the local Chinese community and the Chinese embassy. The Chinese media also picked up the story, and the controversy ultimately led to the episode being deleted from Telecinco's website.

All three examples considered so far - Germany, Italy and Spain - have demonstrated the limitations of a multicultural dining scene. In each case, migrant cuisines in the culinary marketplace exist alongside culinary xenophobia. In public discussion, food multiculturalism is often seen as a sign of openness to other cultures. However, the examples we have furnished so far show that it is unclear to what degree, if at all, 'experiences of 'otherness' through food [...] contribute to positive relationships across difference'. ${ }^{70}$ Elspeth Probyn (2000) argues that '[e]ating [...] metaphors are often used to cover over other nasty bits: the hearty enthusiasm for 'foreign' food that is supposed to hide the taste of racism'. ${ }^{71}$ The cases of Germany, Italy and Spain bear this out. The least that can be said of culinary multiculturalism in these countries is that 'culinary acceptance [...] is not necessarily a signifier of acceptance or understanding' ${ }^{72}$ Australian sociologist Ghassan Hage criticizes the 'cosmo-multiculturalism' that is experienced by the eating public as limited, arguing instead for the idea of a more authentic 'home-building multiculturalism' that takes place in private homes. 73 In contrast to cosmo-multiculturalism, which occurs in restaurants and is centred on consumers, Hage uses data on Lebanese migrants in Australia to show that a different version of multiculturalism takes place in people's homes.

The potential of a 'home-building' approach to food multiculturalism is in evidence in Catalonia, which is home to around 20\% of Spain's foreign population. One of the most important social problems facing Catalonia is the integration of migrant groups: there are around one million foreign residents, the majority being from Morocco, followed by Romania and then Ecuador.74 Catalonia positions itself quite differently to the rest of Spain when it comes to cultural diversity. A celebrated feature of Catalan identity in public discourse and public culture is openness to other cultures, often cited as a reason why Catalonia has been able to accommodate such high levels of migration. 75 This apparent openness to other cultures is reflected in the attitude to foreign cuisines in Catalonia. In a recent article on Catalan gastronomy, Anton Pujol highlights how important it has been for the Generalitat, the Catalan government, to position both Catalan cuisine and Catalan culture more broadly as 'open to new horizons'. ${ }^{6}$ The Generalitat, according to Pujol, made the most of the celebrations around the Catalan 'year of gastronomy' to strengthen the cultural construction of Catalonia as a community that is accepting of other cultures. 77 Nowhere is this more evident than in

\footnotetext{
${ }^{69}$ El Mundo, 21 May 2014, 'Los chinos se enfadan con “Aída”, accessed 16 July 2015, http://www.elmundo.es/television/2014/05/21/537ccoac22601de01a8b4575.html

$7^{0}$ Amanda Wise, 'Moving Food: Gustatory Commensality and Disjuncture In Everyday Multiculturalism', New Formations, Vol. 74, 2011: p. 85.

${ }^{71}$ Elspeth Probyn, Carnal Appetites: foodsexidentities, London: Routledge, 200o, p. 2.

72 Donna Gabaccia, 'Nations of Immigrants: Do Words Matter', The Pluralist, Vol. 5, No. 3, Fall 2010: p. 23.

73 Ghassan Hage, 'At Home in the Entrails of the West: Multiculturalism, Ethnic Food and Migrant Home-

Building' in Helen Grace (ed.), Home/world: Space, Community and Marginality in Sydney's West, Annandale: Pluto Press, 1997, pp. 99-153.

74 Immigration, Here and Now: Catalonia, Statistical Institute of Catalonia Generalitat de Catalunya, Barcelona: 2009, accessed 15 May 2015, http://citiesofmigration.ca/elibrary/immigration-here-and-now-catalonia/

75 Turisme de Barcelona, L'any del menjar, cuina i gastronomia, 2005, accessed 24 May 2015, http://www.barcelonaturisme.com/imgfiles/adg/dossierang.pdf

${ }^{76}$ Anton Pujol, 'Cosmopolitan Taste: The Morphing of the New Catalan Cuisine', Food, Culture and Society, Vol. 12, No. 4, 2009, p. 444.

77 ibid., pp. 444-445.
} 
the Generalitat's claim in a publicity brochure for the Year of the Gastronomy celebrations that 'many cultures live side by side in Barcelona and Catalonia', and that these would occupy an important place in the culinary festivities. ${ }^{8}$ This open, cosmopolitan view of Catalonia also circulates in television portrayals of Catalonia and Catalan cuisine, as we will discuss now by looking at a critically acclaimed television food program, Karakia.

Produced by Canal 33 since 2001, the state-commissioned television series Karakia is part of a broader attempt by the Generalitat to promote diversity and build socially cohesive relations in an increasingly multicultural Catalonia. Working with Televisió de Catalunya from the late 1990s, the show's director Josep Mulet and his team looked for ways to connect with new immigrant communities and to help Catalan viewers to learn about and open up to new cultures, putting aside many of the prejudices reported in more mainstream media. It was decided that a focus on cuisine would provide an ideal window into other ways of life, which in many instances were very different from Catalan traditions. As a basic language shared and appreciated by everybody, food was embraced as the ideal universal medium through which to teach and learn about 'foreign' cultures. Now considered ground-breaking in Europe for its treatment of diversity, Karakia was launched a few months before UNESCO proclaimed the Universal Declaration on Cultural Diversity in 2001. The program, which has become 'one of TVC's most popular and widely viewed programs, averaging 185, ooo viewers and a total screen share of $7.2 \%$, 79 has its hosts visit the homes of foreign-born residents in Catalonia, where they and the program's viewers learn about the cuisine and culture of the featured families. The migrant groups - from countries as far away as New Zealand and as nearby as Italy - take centre stage in this program as they cook some of their favourite dishes and talk about their culture, as well as their experiences of migration to Catalonia. Family and friends are often invited to help with the cooking and/or join in the meal afterwards, allowing the program to underscore the importance of interaction between different cultural subjects in the context of an increasingly multicultural society.

A central premise of Karakia is that food multiculturalism - that is, the consumption of or learning about different 'ethnic' cuisines - promotes more positive intercultural relations. The concept of food multiculturalism and what it might mean for intercultural relations has been the subject of a great deal of debate in public discourse and scholarship. Much of the critique around food multiculturalism is based on the belief that when we consume another cuisine (either metaphorically or literally), we run the risk of slipping into patterns of colonialism. ${ }^{80}$ Home-building multiculturalism - the model of food multiculturalism adopted in Karakia - is posited as a corrective to these potentially damaging culinary encounters. Also significant to the food multiculturalism plated up in this program is the agency it allows the migrant subjects, who feature as the 'protagonists, cooking their nation's typical dishes and sharing them with friends and family'. ${ }^{81}$ Karakia films migrants shopping for food or in their homes cooking, in contrast to most television food series, in which hosts are filmed 'discovering' cuisines and/or literally and metaphorically 'eating' their way through regions or countries. Karakia's host is only ever heard as a voiceover when a summary

\footnotetext{
78 ibid., p. 444.

79 Cities of Inclusion, 'Karakia: Cooking Up Inclusion', 9 December 2010, accessed 12 August 2014, http://citiesofmigration.ca/good_idea/recipes-for-inclusion/

80 See Lisa Stowe and Dawn Johnston, 'Throw Your Napkin on the Floor: Authenticity, Culinary Tourism, and a

Pedagogy of the Senses', Australian Journal of Adult Learning, Vol. 52, No. 3, 2012: pp. 460-483.

${ }^{81}$ Lara Anderson, 'Interview with Josep Mulet', 20 September 2014.
} 
of events is required or extra historical and cultural information about the migrant's country of origin is given. When asked about the agency of Karakia's migrant subjects and the authority they have to decide on which aspects of their culture and cuisine will be presented, Mulet explained that 'a script is pretty much non-existent, there's just a filming schedule'. ${ }^{82}$ Filming each episode in real time, with what he describes as minimal intervention, Mulet asserts that though this is a much slower process, in this way each migrant has maximum control of the images of his/her community that the program puts into circulation. With such a progressive treatment of migrant communities and their cuisines, Karakia has been celebrated as performing what one scholar describes as a 'civic and public service'. 83

Another aspect of Mulet's multicultural food series that is different to other more canonical food series is that there are no shots of non-migrant hosts 'consuming' the cuisine of a region or country. This type of image serves to undermine the agency of the relevant culture as it reinforces the notion that 'ethnic' cuisine is intended for consumption by a 'host' culture. Indeed, at the end of each episode, when the show's dishes are consumed, it is by the migrant and the friends and family that he/she has invited. Such an innovative shift of focus means that Karakia addresses some of the main criticisms of food multiculturalism. The migrant subjects exercise their agency to teach viewers to make dishes that are culturally or personally significant, and in this sense Karakia steers clear of what has been described as a food multiculturalism devoid of 'ethnics'. 84 The fact that most of the program is filmed in the personal dwellings of the migrants is also important to extant critiques of food multiculturalism. Although the first series told the stories of migrant restaurant owners, Mulet soon realized the advantages of filming migrants in their homes and, as one journalist has written about this aspect of Karakia, it goes even further: it gets into the houses of immigrants, literally into their kitchens, and adopts the slow pace of the domestic stove-top to narrate the different communities' stories and customs. ${ }^{85}$ Karakia gives agency to migrant subjects, who not only appear as the protagonists of the program but also shape the script, instead of depicting the 'devouring' of regional and or ethnic cuisines by the ethnic majority. In this way it transcends the limitations of a food multiculturalism that is centred on the enjoyment of ethnic cuisines by majority consumers, which, as we saw in the cases of Germany, Italy and greater Spain, does not preclude the rejection of the migrant group behind the cuisine.

\section{Conclusion}

As food historian Stephen Mennell has noted, food is 'a potent ingredient of national and social stereotyping'. ${ }^{6}$ Thus, exploring attitudes towards migrants via the prism of their culinary cultures provides a unique view of the acceptance or rejection of cultural diversity in Europe. Because food and eating practices invoke the physicality of the body, they are 'highly sensitive to shifting configurations of risk and trust'. 87 We see the tensions that have arisen in Europe around immigration in a range of contexts: in Germany's love-hate relationship with migrants and their food; in the attempts to

\footnotetext{
82 ibid.

83 Jordi Xifra, 'Unfreezing Ethnicity as Culture in Public Relations: Immigrant Image and Static Categories in an Age of Liquid Fear.' Comunicaçao Pública Vol. 6, No. 10, 2011, http://cp.revues.org/433

84 Hage, 1997.

85 El País, 17 May 2003, 'El sabor de la diversidad', X. Moret, accessed 16 July 2015, http://elpais.com/diario/2003/o5/17/catalunya/1053133642_850215.html

86 Mennell, 2005, pp. 280-281.

87 Lien, 2004, p. 10.
} 
'fortify' regional cuisines in Italy; and in Catalonia's attempts to promote multicultural culinary 'home-building' as a point of difference from Spanish culinary xenophobia. These tensions exist in the context of increasing European integration and the concomitant protectionism that attends European culinary identities. In asserting the continuing relevance of culinary nationalism, Priscilla Parkhurst Ferguson declares that 'more and more countries propose culinary distinction as a marker of identity', the movement of goods and the blurring of borders notwithstanding. ${ }^{88}$ Indeed, regions that aspire to nationhood - such as the Spanish region of Catalonia - engage actively in promoting their edible traditions and indigenous foods to tourists and trading partners. One of the most appealing aspects of European culture may be its culinary diversity - and this is a diversity that recent extra-European migration has further enhanced - but food is also one of the most potent points of intercultural contention in Europe, and the vehicle for some disturbing xenophobic sentiment. In this context, more attention needs to be paid to the crucial role of food in migrant 'home-building' in Europe.

88 Parkhurst Ferguson, 2010, p. 105. 